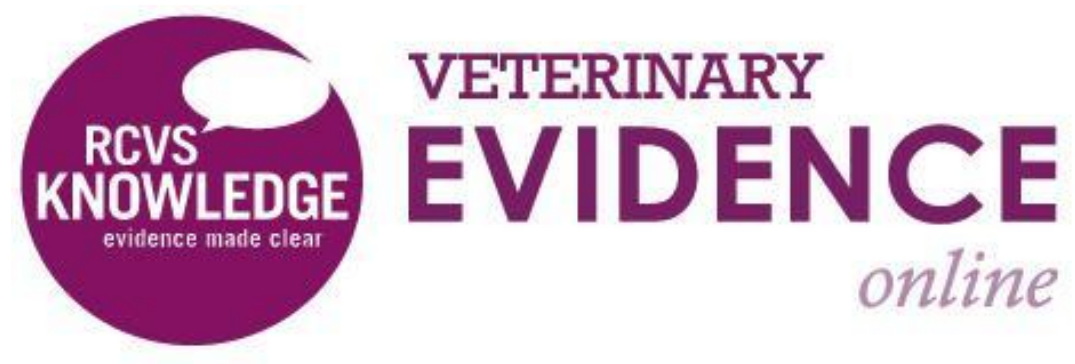

\title{
In Cats Infected With Feline Herpesvirus Type-1 (FHV- 1) Does Treatment With Famciclovir Result in a Reduction of Respiratory and Ocular Clinical Signs?
}

\author{
A Knowledge Summary by \\ Jacqueline Cole BSc, BVetMed, MRCVS ${ }^{1 *}$ \\ ${ }^{1}$ University of Bristol, Senate House, Tyndall Ave, Bristol BS8 1TH
${ }^{*}$ Corresponding Author (jc16689@my.bristol.ac.uk)
}

ISSN: 2396-9776

Published: 05 July 2017

in: Vol 2, Issue 3

DOI: http://dx.doi.org/10.18849/ve.v2i3.105

Reviewed by: Myra Forster-van Hyfte (CertVR, CertSAM, DipECVIM-cA, FRCVS) and Eva Spada (DVM, PhD) 
KNOWLEDGE SUMMARY

\section{Clinical bottom line}

Based on the current available evidence, famciclovir may have a positive effect on reducing respiratory and ocular clinical signs of feline herpesvirus type-1 (FHV-1) disease, however further research is needed before famciclovir can be routinely recommended as part of a treatment protocol for this disease.

\section{Question}

In cats infected with feline herpesvirus type-1 (FHV-1), does treatment with famciclovir result in a reduction of respiratory and ocular clinical signs?

\section{Clinical Scenario}

You are presented with a 3 year old male neutered domestic shorthair that has non-resolving rhinitis, previously treated with two different antibiotics. You have taken an oropharyngeal swab, which has come back positive for FHV-1. A colleague recommends trying the antiviral drug famciclovir. As the drug can be expensive you are unsure whether it is worth trying.

\section{Summary of the evidence}

\begin{tabular}{|c|c|}
\hline & \\
\hline Population: & $\begin{array}{l}\text { Client owned cats split between Australia (5), Europe (1), and USA } \\
\text { (4). Four had ocular disease, two had rhinosinusitis and four had } \\
\text { FHV-1 associated dermatitis }\end{array}$ \\
\hline Sample size: & $\mathrm{N}=10$ \\
\hline Intervention details & $\begin{array}{l}\text { - } 4 \text { cats with primary ocular disease were treated with } \\
62.5 \mathrm{mg} \text { famciclovir once daily for } 7 \text { days, then changing to } \\
\text { twice daily except one cat who appeared to only be given a } \\
\text { once daily dose. Treatment length varied, with the } 1^{\text {st }} \text { cat } \\
\text { being treated for } 35 \text { days, the } 2^{\text {nd }} \text { cat was treated for } 43 \\
\text { days, the } 3^{\text {rd }} \text { cat had no treatment length reported, and the } \\
4^{\text {th }} \text { cat was treated for } 14 \text { days. } \\
\text { - } 2 \text { cats were diagnosed with presumptive FHV-1 associated } \\
\text { rhinosinusitis. One was treated with } 62.5 \mathrm{mg} \text { of famciclovir } \\
\text { once daily for } 4 \text { months, the } 2^{\text {nd }} \text { was treated with } 62.5 \mathrm{mg} \text { of } \\
\text { famciclovir once daily for } 7 \text { days then twice daily for a total } \\
\text { of } 5 \text { weeks. } \\
5 \text { cats had confirmed FHV-1 associated dermatitis, } 4 \text { were } \\
\text { treated with } 125 \mathrm{mg} \text { of famciclovir three times daily for } 2-6 \\
\text { weeks and } 1 \text { was treated with an acyclovir cream that was } \\
\text { applied to the lesions three to four times daily for an }\end{array}$ \\
\hline
\end{tabular}




\begin{tabular}{|c|c|}
\hline & unconfirmed length of time. \\
\hline Study design: & Case series \\
\hline Outcome studied: & $\begin{array}{l}\text { Whether famciclovir would be effective in reducing clinical signs in } \\
\text { ocular, respiratory and dermatological diseases caused by } \\
\text { presumptive FHV-1 infection }\end{array}$ \\
\hline $\begin{array}{l}\text { Main findings: } \\
\text { (relevant to PICO question): }\end{array}$ & $\begin{array}{l}\text { - In cats with presumptive FHV-1 ocular disease, famciclovir } \\
\text { treatment reduced conjunctivitis, blepharospasm, epiphora, } \\
\text { and increased re-epithelisation of the cornea. Corneal } \\
\text { sequesta detached in } 2 \text { out of } 3 \text { cats treated } \\
\text { - In } 2 \text { cases of presumptive FHV-1 associated rhinitis, } \\
\text { famciclovir showed a clinical improvement, especially when } \\
\text { combined with antibiotics. } \\
\text { - In } 4 \text { cases of confirmed (via viral inclusion bodies in skin } \\
\text { biopsies) of FHV-1 associated dermatitis, all showed } \\
\text { improvement with treatment, with } 3 \text { relapsing when } \\
\text { antiviral therapy was stopped. }\end{array}$ \\
\hline Limitations: & $\begin{array}{l}\text { - Being case reports, treatment differed between the } \\
\text { patients, and was subjective as it was not blinded, and } \\
\text { clinical data and follow-up was limited } \\
\text { - Cats presented with different clinical signs and the majority } \\
\text { were diagnosed presumptively with FHV-1. Three likely had } \\
\text { confirmed FHV-1 via inclusion bodies noted on skin biopsy } \\
\text { samples, the rest having no definitive diagnosis confirmed } \\
\text { via laboratory assessment. } \\
\text { - Dose given and frequency differed between the cats } \\
\text { - One of the cats was not treated with famciclovir, but } \\
\text { - Somother anti-viral agent due to sourcing issues } \\
\text { course of treatment that included antibiotics, } \\
\text { immunosuppressives, and L-lysine } \\
\text { - As the cats were from different countries, there was } \\
\text { possible differences in formulation sourcing of famciclovir } \\
\text { - No negative control group was included }\end{array}$ \\
\hline
\end{tabular}

\begin{tabular}{|r|r|r|}
\hline \multicolumn{1}{|l|}{ Thomasy (2011) } \\
\hline Population: & Non-vaccinated specific pathogen-free cats \\
\hline Intervention Details & $\mathrm{N}=16$ \\
\hline & $\begin{array}{r}\text { Cats were inoculated with FHV-1 and then administered } \\
\text { either } 90 \mathrm{~kg} / \mathrm{kg} \text { of famciclovir or a similar volume of lactose } \\
\text { (the placebo) three times daily for } 21 \text { days. } \\
\text { - Treatment was given at the time of inoculation of the FHV-1 }\end{array}$ \\
\hline
\end{tabular}




\begin{tabular}{|c|c|}
\hline & $\begin{array}{l}\text { (day 0) } \\
\text { Cats were examined prior to, and after inoculation and } \\
\text { treatment twice daily, with a full clinical and ophthalmic } \\
\text { exam. A complete blood count and biochemistry was } \\
\text { performed on each cat before and after inoculation and } \\
\text { treatment course. Biopsies were taken from the } \\
\text { conjunctival fornix of each cat immediately before } \\
\text { inoculation, and on days } 7,14 \text { and } 21 \text {. } \\
\text { - Severity of clinical signs of ocular and non-ocular disease } \\
\text { were scored separately by } 1 \text { or } 2 \text { trained blinded evaluators. } \\
\text { Ocular discharge was scored from } 0 \text { (none) to } 3 \\
\text { (mucopurulent), conjunctivitis was scored from } 0 \text { (none) - } \\
3 \text { ( severe) and blepharspam was scored from } 0 \text { (none) to } 4 \\
\text { (eye completely closed). Non-ocular signs of sneezing were } \\
\text { graded from } 0 \text { (not sneezing) to } 1 \text { (sneezing) and nasal } \\
\text { discharge graded from } 0 \text { (none) to } 3 \text { (marked mucopurulent } \\
\text { discharge). Total clinical disease score was defined as the } \\
\text { sum of all of the ocular and non-ocular scores. } \\
\text { FHV-1 was verified in all cats via serologic testing of blood } \\
\text { and by cytology samples taken inferior conjunctival sac for } \\
\text { qPCR analysis. }\end{array}$ \\
\hline Study design: & Randomised controlled trial \\
\hline Outcome studied: & $\begin{array}{l}\text { To assess the impact of treatment with famciclovir on the clinical } \\
\text { signs and course of disease of cats experimentally infected with } \\
\text { FHV-1 }\end{array}$ \\
\hline $\begin{array}{l}\text { Main findings: } \\
\text { (relevant to PICO question): }\end{array}$ & $\begin{array}{l}\text { - Famciclovir treated cats had significantly lower median total } \\
\text { disease score and histologic conjunctivitis score than cats } \\
\text { treated with the placebo } \\
\text { - There was a significant reduction in serum anti-FHV-1 DNA } \\
\text { titer, serum globulin concentration, and FHV-1 DNA and } \\
\text { RNA viral load from conjunctival samples. Famciclovir } \\
\text { treated cats also had an increased goblet cell density } \\
\text { - Histological conjunctivitis score rate was increased } \\
\text { - } \text { significantly in famciclovir, versus placebo } \\
\text { - } \text { - Frersus placebo } \\
\text { cats (90\% in treated versus } 98 \% \text { in placebo) and FHV-1 DNA } \\
\text { was detected significantly less in treated cats, than placebo } \\
\text { cats }\end{array}$ \\
\hline Limitations: & $\begin{array}{l}\text { - Only } 16 \text { cats in the study, resulting in lower study power } \\
\text { - Food intake was not measured when assessing changes in }\end{array}$ \\
\hline
\end{tabular}




\begin{tabular}{|c|c|}
\hline omasy (2016) & \\
\hline Population: & $\begin{array}{l}\text { Client owned cats seen at the University of California Davis } \\
\text { Veterinary Medical teaching hospital between June } 1^{\text {st }} 2006 \text { and } \\
\text { May } 30^{\text {th }} 2013\end{array}$ \\
\hline Sample size: & $N=59$ \\
\hline Intervention Details & $\begin{array}{l}\text { - Cats were divided into two groups, } 33 \text { cats had been given } \\
\text { famciclovir at a dose of approx. } 40 \mathrm{mg} / \mathrm{kg} \text { three times daily, } \\
\text { and the other group of } 26 \text { cats were given a dose of approx. } \\
90 \mathrm{mg} / \mathrm{kg} \text { three times daily. Length of treatment varied and } \\
\text { was at the discretion of the attending clinician } \\
\text { Dosage was approximated due to the narrow range of } \\
\text { commercially available tablets, which led to body-weight- } \\
\text { dependent variations from targeted doses. } \\
\text { Retrospective disease severity scoring was performed by } \\
\text { one ophthalmologist to assess clinical improvement post- } \\
\text { treatment. A score of } 1 \text { (mild), } 2 \text { (moderate), } 3 \text { (severe) was } \\
\text { subjectively assigned for the most severely affected tissue } \\
\text { (i.e. conjunctiva) at the initial physical exam and } \\
\text { reassessments using the records of the attending clinician. } \\
\text { The median duration of clinical signs and treatment course } \\
\text { length was calculated for only cats that showed a } \\
\text { documented clinical improvement } \\
\text { The timeframe was from the time the first dose of } \\
\text { famciclovir was given to the first recheck, that varied, that } \\
\text { showed an improvement. Owners were also surveyed } \\
\text { regarding satisfaction with treatment and observations of } \\
\text { improvement using a semi-quantitative scales (1 mild-10 } \\
\text { severe) to rat the severity of their cat's illness before and } \\
\text { after the treatment }\end{array}$ \\
\hline Study design: & Retrospective case series \\
\hline Outcome studied: & $\begin{array}{l}\text { To assess whether famciclovir given at } 90 \mathrm{mg} / \mathrm{kg} \text { three times daily or } \\
40 \mathrm{mg} / \mathrm{kg} \text { three times daily resulted in a reduction of clinical signs of } \\
\text { naturally occurring feline herpesvirus ( } \mathrm{FHV}-1 \text { ) in client owned cats. } \\
\text { As well as to assess variables contributing to owner satisfaction of } \\
\text { each treatment plan. }\end{array}$ \\
\hline $\begin{array}{l}\text { Main findings: } \\
\text { (relevant to PICO question): }\end{array}$ & $\begin{array}{l}\text { - Clinical improvement was observed via the disease severity } \\
\text { scoring in } 50 \text { of } 59 \text { cats in both the } 40 \mathrm{mg} / \mathrm{kg} \text { and } 90 \mathrm{mg} / \mathrm{kg} \\
\text { cohorts. In the owner's assessed disease severity score there } \\
\text { was a significant }(\mathrm{p}<0.001) \text { improvement clinical signs } \\
\text { - The median duration of improvement in clinical signs was } 14\end{array}$ \\
\hline
\end{tabular}




\begin{tabular}{|c|c|}
\hline & $\begin{array}{l}\text { days for the low dose group, and } 7 \text { days for the high dose } \\
\text { group. The treatment course length was } 36 \text { days for the low } \\
\text { dose group, and } 14 \text { days for the high dose group. } \\
\text { - There was a significant difference in improvement }(\mathrm{P}=0.025 \text { ) } \\
\text { in clinical signs and significantly shorter period ( } \mathrm{p}<0.001 \text { ) of } \\
\text { initiation of treatment to improvement for cats in the } \\
90 \mathrm{mg} / \mathrm{kg} \text { cohort versus the } 40 \mathrm{mg} / \mathrm{kg} \text { group } \\
\text { - Number of treatment courses did not differ significantly } \\
\text { between the two treatment groups } \\
\text { Results of the survey reported that } 70 \% \text { of owners found } \\
\text { that clinical signs were improved with treatment of both the } \\
90 \mathrm{mg} / \mathrm{kg} \text { and } 40 \mathrm{mg} / \mathrm{kg} \text { groups and that famciclovir was rated } \\
\text { first of second in effectiveness compared to various other } \\
\text { treatments given. Prior treatments varied per cat, with only } \\
9 \text { cats receiving no other medications prior to the study. The } \\
\text { treatments used prior included antibiotics, antivirals, both } \\
\text { oral and topical, immunosuppressant's and nutraceuticals. }\end{array}$ \\
\hline Limitations: & $\begin{array}{l}\text { - As a retrospective study the dose of famciclovir given was } \\
\text { not masked, and improvements in clinical signs was rated by } \\
\text { different clinicians. } \\
\text { - Prior to study, } 50 \text { of thecats from both groups were } \\
\text { receiving one or more topical or systemic medication as sole } \\
\text { agents or in combination. These drugs included antibiotics, } \\
\text { antivirals (including famciclovir) and anti- } \\
\text { inflammatory/immunosuppressive (prednisone and } \\
\text { megestrol acetate). It is possible that some of the } \\
\text { improvements noted to famciclovir were confounded by } \\
\text { these other medications } \\
\text { - A median of } 3 \text { additional medications were prescribed along } \\
\text { with famciclovir at the time of the study } \\
\text { PCR for FHV-1 DNA was performed in } 10 / 59 \text { cats presenting } \\
\text { for ophthalmological signs with only } 6 \text { of the } 10 \text { being } \\
\text { positive. } 4 \text { cats who did not have ophthalmological signs } \\
\text { were not tested } \\
\text { The manufacturer of the famciclovir was identified for only } \\
59 \% \text { of cases, with other sources being unidentified. This } \\
\text { could have affected the differences noted between the high } \\
\text { dose and low dose cohorts } \\
\text { - The course length of treatment and follow up time differed } \\
\text { between the cats and as some cats had chronic signs before } \\
\text { being included in the study, their improvement may have } \\
\text { been because of the natural course of the disease process } \\
\text { As famciclovir was more costly, owners may have been more } \\
\text { bias on whether their cats improved on it }\end{array}$ \\
\hline
\end{tabular}




\section{Appraisal, application and reflection}

The available evidence studied varied between retrospective cases series, to case reports, to randomised controlled studies. Each of these differed in what they were assessing, whether ocular, respiratory or dermatological disease and treatment design and length of treatment courses varied. There was also a range of famciclovir dosing regimens used in cats, demonstrating the knowledge gap in ascertaining the most appropriate dose for treatment FHV-1 in cats.

There was confounding variables in some of the studies that may have impacted on clinical improvements attributed to famciclovir treatment. One was that many of the cats had been treated with or were on other medications before and during some of the studies such as in Thomasy et al (2016) and Malik et al (2009). Another was that in some of the studies, the full history of the previous treatments given were unknown or incomplete as some were case reports from multiple sources as in Malik et al (2009). Apart from Thomasy et al (2011), in the majority of the cats in the studies evaluated, FHV-1 was the presumptive cause of clinical signs and was not confirmed via laboratory testing. Also in Thomasy et al (2011) the first dose of famciclovir was given at the same time of inoculation with the virus. This leaves to question whether famciclovir is useful when given after the infection becomes clinically apparent. Thus, more research would be needed on timing of when treatment is started. Despite these shortcomings, the cats in the studies that had confirmed FHV-1 infection, treatment with famciclovir did appear to have a significant positive effect in reducing respiratory and ocular clinical signs, in a similar pattern to the ones given a presumptive diagnosis. Ideally more studies like Thomasy et al (2011), would need to be performed, with a confirmed diagnosis, and set treatment protocols to provide a stronger evidence base, as well as a basis for better treatment guidelines for the use of famciclovir in general and referral practice.

\section{Methodology Section}

\begin{tabular}{|c|c|}
\hline $\begin{array}{l}\text { Databases searched and dates } \\
\text { covered: }\end{array}$ & $\begin{array}{l}\text { The following search terms were applied to the CAB abstracts } \\
\text { database (1973-2016) via the OVID Platform and the Medline } \\
\text { database accessed via the NCBI website (1946-2016) }\end{array}$ \\
\hline \multirow[t]{2}{*}{ Search terms: } & $\begin{array}{l}\text { CAB Abstracts search terms: Cats/ or (cat or cats or feline or felis or } \\
\text { felid).mp AND felid herpesviruses/ or felid herpesvirus } 1 \text { / or } \\
\text { herpes/ or (herpesviruses or fhv or fhv-1 or herpesvirus or } \\
\text { herpes).mp AND famciclovir/ or (famcycovir or famciclovir) }\end{array}$ \\
\hline & $\begin{array}{l}\text { Medline search terms Cats/ OR (cat or cats or feline or felis or } \\
\text { felid).mp AND Herpesviridae/ OR (herpesviruses or fhv or fhv-1 or } \\
\text { herpesvirus or herpes) AND (famcycovir or famciclovir or famvir) }\end{array}$ \\
\hline Dates searches performed: & 24 November 2016 \\
\hline
\end{tabular}

\begin{tabular}{|c|c|}
\hline \multicolumn{2}{|l|}{ Exclusion / Inclusion Criteria } \\
\hline Exclusion: & $\begin{array}{l}\text { In vitro studies, conference proceedings, review articles, book } \\
\text { chapters, articles not relevant to the PICO }\end{array}$ \\
\hline Inclusion: & $\begin{array}{l}\text { In vivo studies, articles relevant to the PICO, articles that had more } \\
\text { than one animal. Studies that only used oral famciclovir as the } \\
\text { antiviral. }\end{array}$ \\
\hline
\end{tabular}




\begin{tabular}{|c|c|c|c|c|c|}
\hline \multicolumn{6}{|c|}{ Search Outcome } \\
\hline Database & $\begin{array}{l}\text { Number } \\
\text { of results }\end{array}$ & $\begin{array}{c}\text { Excluded - in vitro } \\
\text { studies }\end{array}$ & $\begin{array}{c}\text { Excluded - single case } \\
\text { report/book } \\
\text { chapter/conference } \\
\text { proceeding/review articles }\end{array}$ & $\begin{array}{l}\text { Excluded }- \text { not } \\
\text { relevant to the } \\
\text { PICO }\end{array}$ & $\begin{array}{l}\text { Total } \\
\text { relevant } \\
\text { papers }\end{array}$ \\
\hline $\begin{array}{l}\text { CAB } \\
\text { Abstracts }\end{array}$ & 15 & 2 & 6 & 5 & 2 \\
\hline $\begin{array}{l}\text { NCBI } \\
\text { PubMed }\end{array}$ & 14 & 3 & 1 & 6 & 4 \\
\hline \multicolumn{5}{|c|}{ Total relevant papers when duplicates removed } & 2 \\
\hline
\end{tabular}

\section{CONFLICT OF INTEREST}

The author declares no conflict of interest.

Assisted with Medline and CAB search by Mrs. Emma Place BSc MA Subject Librarian at the University of Bristol.

\section{REFERENCES}

1. Malik, R. Lessels, et al (2009) Treatment of feline herpesvirus-1 associated disease in cats with famciclovir and related drugs. Journal of Feline Medicine and Surgery, 11 (1), pp. 40-

48. http://dx.doi.org/10.1016/i.jfms.2008.11.012

2. Thomasy, S.M. et al (2011) Evaluation of orally administered famciclovir in cats experimentally infected with feline herpesvirus type-1. American Journal of Veterinary Research, 72 (1), pp. 85 95. http://dx.doi.org/10.2460/ajvr.72.1.85

3. Thomasy, S.M. (2016) Oral administration of famciclovir for treatment of spontaneous ocular, respiratory, or dermatologic disease attributed to feline herpesvirus type 1: 59 cases (20062013). Journal of the American Veterinary Medical Association, 249 (5), pp. 526-

538. http://dx.doi.org/10.2460/javma.249.5.526 


\section{Intellectual Property Rights}

Knowledge Summaries are a peer-reviewed article type which aims to answer a clinical question based on the best available current evidence. It does not override the responsibility

of the practitioner. Informed decisions should be made by considering such factors as individual clinical expertise and judgement along with patient's circumstances and owners' values. Knowledge Summaries are a resource to help inform and any opinions expressed within the Knowledge Summaries are the author's own and do not necessarily reflect the view of the RCVS Knowledge.

Authors of Knowledge Summaries submitted to RCVS Knowledge for publication will retain copyright in their work, but will be required to grant to RCVS Knowledge an exclusive license of the rights of copyright in the materials including but not limited to the right to publish, re-

publish, transmit, sell, distribute and otherwise use the materials in all languages and all media throughout the world, and to license or permit others to do so.

Authors will be required to complete a license for publication form, and will in return retain certain rights as detailed on the form.

Veterinary Evidence and EBVM Network are RCVS Knowledge initiatives. For more information please contact us at editor@veterinaryevidence.org

RCVS Knowledge is the independent charity associated with the Royal College of Veterinary Surgeons (RCVS). Our ambition is to become a global intermediary for evidence based veterinary knowledge by providing access to information

that is of immediate value to practicing veterinary professionals and directly contributes to evidence based clinical decision-making.

www.veterinaryevidence.org

RCVS Knowledge is a registered Charity No. 230886. Registered as a Company limited by guarantee in England and Wales No. 598443.

Registered Office:

Belgravia House

62-64 Horseferry Road

London SW1P 2AF 